Egyptian Journal of Aquatic Biology and Fisheries

Zoology Department, Faculty of Science,

Ain Shams University, Cairo, Egypt.

ISSN $1110-6131$

Vol. 25(1): $279-292(2021)$

www.ejabf.journals.ekb.eg

\title{
Evaluation of Different Sex Reversal Treatments in Red Tilapia Hybrid
}

Fatma M. Zaki ${ }^{1 *}$, Mohamed M. Said ${ }^{1}$, Al-Azab Tahoun ${ }^{1,}$ and Mohamed Amer ${ }^{2}$

1. Department of Aquaculture, Faculty of Fish Resources, Suez University, Suez, Egypt

2. Department of Animal Production, Faculty of Agriculture, Ain shams University, Egypt

*Corresponding Author: fatmazaki717@gmail.com

\begin{abstract}
ARTICLE INFO
Article History:

Received: Dec. 16, 2020

Accepted: Jan. 15, 2021

Online: Jan. 18, 2021

Keywords:

Red Tilapia,

Sex reversal,

$17 \alpha$-methyltestosterone,

Tribiulus terrestris,

Growth performance,

Feed utilization.

\section{ABSTRACT}

Effects of dietary inclusion of Tribulus terrestris and $17 \alpha$ methyltestosterone on sex reversal, growth performance, feed utilization, and survival rates of red tilapia were evaluated in this study. Red tilapia fry with an average weight of $0.02 \pm 0.003 \mathrm{~g}$ and an average length of 0.6 $\pm 0.012 \mathrm{~cm}$ were subjected to six different sex reversal treatments. The experiment lasted for 112 days. Two T. terrestris extract treatments (1 and 2 $\mathrm{g} / \mathrm{kg}$ diet); three hormonal treatments with $17 \alpha$-methyltestosterone ( 30,60 and $100 \mathrm{mg} / \mathrm{kg} \mathrm{diet}$ ), were applied in this experiment plus a control group. The results of this study revealed that all plant and hormonal treatment showed significantly higher male percentages $(\mathrm{p} \leq 0.05)$ than the control. The highest male percentage of $(90 \%)$ was achieved at the dose of $60 \mathrm{mg} 17 \alpha$ methyltestosterone $/ \mathrm{kg}$ followed by $T$. terrestris extract at $2 \mathrm{~g} / \mathrm{kg}$ with a male percentage of $(84.4 \%)$. Growth performance and feed utilization of red tilapia were better in the two treatments of T.terrestris extract, followed by the hormonal dose $60 \mathrm{mg} / \mathrm{kg}$ diet, than other treatments. A significantly higher survival rate of $85.44 \%, 83.33 \%$, and $83.11 \%$ was achieved at 1 and $2 \mathrm{~g} \mathrm{~T}$. terrestris extract $/ \mathrm{kg}$ and the control respectively. The lowest survival $(71.56 \%)$ was observed at the $100 \mathrm{mg} 17 \alpha-\mathrm{MT} / \mathrm{kg}$ diet $(\mathrm{p} \leq .05)$. Testes weight was significantly higher at $2 \mathrm{~g} \mathrm{~T}$. terrestris extract $/ \mathrm{kg}$ diet treatment compared with the other treatments and the control. The highest male gonado-somatic index records were found at the control and $2 \mathrm{~g} \mathrm{~T}$. terrestris extract/ $\mathrm{kg}$ diet treatments. Conclusively, the addition of $T$. terrestris extract and $17 \alpha-\mathrm{MT}$ into red tilapia hybrid fry diets contributes in producing almost all-male tilapia population and enhancing growth performance and feed utilization of the fish.
\end{abstract}

\section{INTRODUCTION}

Aquaculture is considered a worldwide essential industry that provides people with cheap and significant animal protein source supporting the world food security. Globally, the average consumption of this animal protein source is 17 percent (FAO, 2020). Notably, Egypt has been recorded the biggest African country and the sixth worldwide in aquaculture production (FAO, 2020). In 2017, aquaculture production was about $80.71 \%$ of total Egyptian fish production, while fisheries production recorded a percentage of only 19.29 which represented a high increase in aquaculture share compared to $47 \%$ in 2000 (GAFRD, 2018). 
The characteristics of red tilapia qualify it to gain a worldly high popularity due to their high growth rates, attractive skin color (it resembles some marine species), tolerance to high salinity, and relatively high price (Thodesen et al., 2013). In spite of the upper- mentioned advantages of red tilapia culture, Egyptian aquaculture production seems to introduce an un-significant production of red tilapia.

In fact, Red tilapia males grow faster than females, additionally, there is a significant difficulty facing tilapia culture as tilapia mature early in the tropics and captivity, a problem that could be solved by slowing their growth via competition for food and space (Basavaraja, 1991). Consequently, techniques for the production of all male tilapia populations involves manual sexing by differentiating sexes visually, genetic manipulation ,hybridization, and sex reversal through exogenous steroid administration (Phelps \& Popma, 2000). A highly effective method in inducing sex reversal in tilapia and tilapia hybrids is the use of synthetic androgen hormones in the early life stages of tilapia fry (Guerrero \& Guerrero , 1988). Many methods have been used for introducing androgens to fish including oral administration and fry immersion in steroid solutions (Fuentes-Silva et al., 2013). In addition, Many plants have been used in producing a predominantly male population of tilapia in aquaculture (Khakong et al., 2011; Ghosal et al., 2015 and Gabriel et al., 2017)

Thie present study was conducted to evaluate different sex reversal treatments in order to optimize seed production practices in red tilapia hatcheries in Egypt.

\section{MATERIALS AND METHODS}

\section{Fish specimens}

Two days old red tilapia fry (Florida strain) were transferred from the General Authority of Fish Resources Development (GAFRD) hatchery located at km 21of the Alexandria-Cairo high way in oxygenated plastic bags. Initial mean weight and length of experimental fish were $0.02 \pm 0.003 \mathrm{~g}$ and $0.6 \pm 0.012 \mathrm{~cm}$, respectively. fish fries were distributed among 18 plastic tanks (60 liter for each) at stocking density of 6 fry/ one. Fries were acclimated from $10 \mathrm{ppt}$ to $0.5 \mathrm{ppt}$ in 5 days as water salinity was reduced by two degrees each day. The experiment was conducted at aquaculture lab in the Faculty of Fish Resources, Suez University, Suez, Eygpt. The experiment lasted for 112 days beginning from the $20^{\text {th }}$ of August 2019 till the $10^{\text {th }}$ of December 2019.

\section{Experimental Design}

The experiment was conducted using a completely randomized design. The experiment consisted of six treatments including control group $\left(\mathrm{T}_{1}\right)$, two plant (Tribulus. Terrestris) extraction treatments with 1 and $2 \mathrm{~g} / \mathrm{kg}$ feed $\left(\mathrm{T}_{2}\right.$ and $\left.\mathrm{T}_{3}\right)$; three $17 \alpha$-MT hormonal treatments with 30,60 and $100 \mathrm{mg} / \mathrm{kg}$ feed $\left(\mathrm{T}_{4}, \mathrm{~T}_{5}\right.$ and $\left.\mathrm{T}_{6}\right)$; Fish in the control were fed with a basal diet without any addition of hormone or plant extraction. Moreover, feeding for all experimental groups with the hormone and plant extract lasted for a period of 28 days concerning the $1^{\text {st }}$ treatment, followed by a threemonths rearing fed on a basal diet.

Twenty fish from each experimental tank (Total 18 tanks: 6 treatments and 3 replicats) were randomly selected every week, measurement of length and evaluation of weight were recorded to determine different growth performance and feed 
utilization parameters. At the end of the experiment, sex ratio, survival rate, gonads weight, and gonado-somatic index were all determined.

\section{$\underline{\text { Experimental management }}$}

All experimental tanks (circular 60 litre for each) were aerated using air line attached to air blower which compress air in the tanks through air stones all the day long. De-chlorinated tap water was utilized as the fresh water source for water management at the beginning of the experiment; saline water (42 ppt) was brought from Suez Gulf and transferred in plastic pails. Water quality parameters were measured daily to ensure proper water quality for the experimental fish. Fish were fed five times a day at the beginning of the experiment which was, afterwards, reduced to three times daily. Each treatment was fed with $15 \%$ of their biomass for the first 14 days of the experiment and then the percentage was reduced to $10 \%$ for the rest of the experiment. Samples of fish were weighed every two weeks and the feed quantity was adjusted accordingly. A fine commercial powder feed containing $40 \%$ crude protein (Skritting Egypt ${ }^{\circledR}$ ) was used for the first 28 days of the experiment while pelleted (1.2 $\mathrm{mm}$ ) commercial fish feed containing $30 \%$ crude protein (Grand Aqua ${ }^{\circledR}$ ) was used for the rest of the experiment. Water quality parameters were maintained within the acceptable ranges; as different water quantities were replaced with clean water daily. Water temperature, $\mathrm{pH}$, dissolved oxygen and water ammonia were measured daily. Water temperature ranged from 16.9 to $29.67^{\circ} \mathrm{C}$, dissolved oxygen ranged from 5.76 to $6.05 \mathrm{mg} / \mathrm{l}$, water $\mathrm{pH}$ raged from 7.6 to $7.8 \mathrm{mg} / \mathrm{l}$, whereas the total ammonia ranged from 0.06 to $0.18 \mathrm{mg} / \mathrm{l}$.

\section{Growth performance and feed utilization parameters:}

Growth performance parameters (weight gain "WG, g", length gain "LG, mm", specific growth rate "SGR, \% day ${ }^{-1,}$ ); while feed utilization parameters (feed conversion ratio "FCR" and protein efficiency ratio "PER") were calculated according to Ugonna et al. (2018).

\section{Survival and sex reversal measurements:}

At the end of the experiment, fish in each tank were netted, and counted for survival rate determination. Sex ratio was determined through dissecting selected 30 fish from each tank randomly, and thence, visually examining their gonads. Additionly, gonadosomatic index was calculated according to the method of Amtyaz et al. (2013) by randomly selecting 10 fish from each tank and determining body weight and gonads weight for each fish.

\section{Statistical analysis.}

Data was analyzed using Statistical Package for Social Science (SPSS) version 22 (2014). One-way ANOVA in SPSS was used to analyze the data of growth performance and feed utilization. Sex ratio and survival rate were analyzed using chisquare (Basavaraja \& Raghavendra, 2017). Duncan's test was used to determine the significance $(p \leq 0.05)$ for differences among different experimental treatments. 


\section{RESULTS AND DISCUSSION}

\section{Growth performance}

Growth performance parameters of red tilapia fry reared under different sex reversal treatments for a period of 28 days were summarized in Table (1). Results showed that the highest weight gain was achieved at the two plant extract treatments (1 and $2 \mathrm{~g}$ T.terrestris/kg diet) with (0.256 g and $0.244 \mathrm{~g}$., respectively).The lowest weight gain was recorded for the hormone inclusion level of $100 \mathrm{mg} 17 \alpha-\mathrm{MT} / \mathrm{Kg}$ (T6) and the control group (T1). A significant reduction $(\mathrm{P} \leq 0.05)$ in body length gain was observed in $\mathrm{T} 1(10 \mathrm{~mm})$ and $\mathrm{T} 6(10.03 \mathrm{~mm})$, while the highest length gain was recorded at T5 (12.53 mm). The highest SGR\% (9.32\%) was recorded for T2 (1 gm T.terrestris/ kg diet ), while the lowest was listed in T6 (100 mg 17a-MT /Kg diet) with $6.096 \%$.

Table 1: Growth performance parameters ( Mean \pm SE) of red tilapia fries (28 days) and fingerlings (whole period of 112 days) after treatment period with different dietary inclusions of Tribulus terrestris extract and 17a-MT.

Growth parameters WG (g) Experimental treatments

\begin{tabular}{|c|c|c|c|c|c|c|c|}
\hline \multicolumn{2}{|c|}{ parameters } & T1 & $\mathbf{T} 2$ & T3 & T4 & T5 & T6 \\
\hline \multirow{9}{*}{ 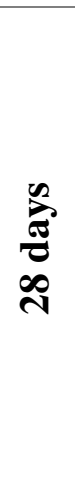 } & WG (g) & $0.0970^{d}$ & $0.2562^{\mathrm{a}}$ & $0.2435^{\mathrm{a}}$ & $0.156^{\mathrm{bc}}$ & $0.1975^{b}$ & $0.115^{\mathrm{cd}}$ \\
\hline & & \pm & \pm & \pm & \pm & \pm & \pm \\
\hline & & 0.0023 & 0.0345 & 0.0003 & 0.003 & 0.0070 & 0.002 \\
\hline & LG (mm) & $10.0^{\mathrm{b}}$ & $11.63^{\mathrm{a}}$ & $11.83^{\mathrm{a}}$ & $11.77^{\mathrm{a}}$ & $12.53^{\mathrm{a}}$ & $10.03^{b}$ \\
\hline & & \pm & \pm & \pm & \pm & \pm & \pm \\
\hline & & 0.251 & 0.484 & 0.233 & 0.406 & 0.233 & 0.433 \\
\hline & SGR (\% day ${ }^{-}$ & $6.307^{\mathrm{d}}$ & $9.3189^{a}$ & $9.208^{\mathrm{a}}$ & $7.76^{\mathrm{b}}$ & $8.519^{\mathrm{ab}}$ & $6.096^{\mathrm{d}}$ \\
\hline & & \pm & \pm & \pm & \pm & \pm & \pm \\
\hline & & 0.1221 & 0.7863 & 0.0068 & 0.092 & 0.2017 & 0.819 \\
\hline \multirow{9}{*}{ 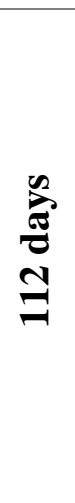 } & WG (g) & $14.27^{b}$ & $19.41^{\mathrm{a}}$ & $18.72^{\mathrm{a}}$ & $18.48^{\mathrm{a}}$ & $18.47^{\mathrm{a}}$ & $14.53^{b}$ \\
\hline & & \pm & \pm & \pm & \pm & \pm & \pm \\
\hline & & 0.26 & 0.21 & 0.38 & 1.72 & 0.46 & 0.32 \\
\hline & LG (mm) & $70.77^{b}$ & $79.57^{\mathrm{a}}$ & $79.10^{\mathrm{a}}$ & $79.47^{\mathrm{a}}$ & $77.13^{\mathrm{a}}$ & $71.53^{b}$ \\
\hline & & \pm & \pm & \pm & \pm & \pm & \pm \\
\hline & & 0.84 & 0.32 & 0.85 & 2.97 & 0.54 & 0.72 \\
\hline & SGR (\% day ${ }^{-}$ & $5.87^{b}$ & $6.14^{\mathrm{a}}$ & $6.12^{\mathrm{a}}$ & $6.09^{\mathrm{a}}$ & $6.10^{\mathrm{a}}$ & $5.88^{b}$ \\
\hline & & \pm & \pm & \pm & \pm & \pm & \pm \\
\hline & & 0.02 & 0.01 & 0.02 & 0.09 & 0.02 & 0.02 \\
\hline
\end{tabular}

*Mean values in the same row with different letters are significantly different $(\mathbf{p}<0.05)$

Growth performance parameters of red tilapia fingerlings after 112 days are shown in Table (1). The results revealed that the highest WG were obtained at T2 
with weight of $19.412 \mathrm{~g}$, and the lowest WG (14.274 g) was recorded at T1. The LG values were highest at $\mathrm{T} 2$ with $(79.57 \mathrm{~mm})$ while the lowest values for the length gain were found at T1 and T6. SGR\% showed similar trend as the weight gain, the highest SGR\% (6.14\%) was recorded in T2 and the lowest SGR\% were found in T6 with $5.88 \%$.

T. terrestris extract treatment in the current study resulted in a significantly higher growth performance in regard to (WG, LG, and SGR\%) in red tilapia.The present findings agreed with those of Omitoyin et al. (2013); Gültepe et al. (2014) and Omar et al. (2014). In addition, results showed high growth performance in hormonal treatments $(30,60$ and $100 \mathrm{mg} / \mathrm{kg}$ feed) than the control group which was in a aparallel line with the results of Khouraiba (1997); Ekwu \& Sikoki (2000) and Ajiboye et al. (2015) who found that the steroid hormones significantly improved the growth performance of the hormonal treated tilapia fry. Many authors recommended $60 \mathrm{mg} 17 \alpha-$ MT / kg diet as the best hormonal treatment (El-Greisy \& El-Gamal, 2012 and Rodmongkoldee \& Leelapat, 2017).

The improvement in growth performance as a result of T.terrestris extract addition in the current work may be due to the phytochemical compounds, mainly the T.terrestris extract such as flavonoids, steroidal sapogenins, and alkaloids which have anti-inflammatory, anti-tumor, and immunomodulatory activities, adding to Gokshur extract which also have antioxidant and hepatoprotective properties (Miller, 1996 \& Kumar et al., 2006 and Allan). Those compounds have been proved to possess a positive effect on fish growth performance (Omitoyin et al., 2013 and Omar et al., 2014), relating that impact to increasing testosterone level (Gauthaman \& Ganesan, 2008) which may be attributed to the improvement in growth performance using the extract.

The improvement in growth of tilapia fry treated with steroid may be due to the anabolic effect of MT and inturn inducing metabolic rates and consequently improving growth indices (Tveiten et al.,1998 and Norbeck \& Sheridan, 2011).

\section{Feed utilization:}

Feed utilization parametrs (feed conversion ratio "FCR", protein efficiency ratio "PER") of red tilapia fry after 28 days of treatment with different sex reversal methods are shown in Table (2).

The results revealed that the best FCR values were obtained at the dietary inclusion of T.terrestris extract at $1 \mathrm{~g} / \mathrm{kg}$ and $2 \mathrm{~g} / \mathrm{kg}$ feed (T2 and T3) with 1.083 and 1.178 respectively. The wrost FCR was recorded in the control (T1) and hormonal concentration of $100 \mathrm{mg} / \mathrm{kg}$ diet (T6) with (2.382 and 2.057, respectivly). Regarding PER the highest values were recorded in the T3 (2.31) and T2 (2.189) and they differed significantly from the other treatments and control. The lowest PER values were recorded in the control group (1.051).

Feed utilization parametres (feed conversion ratio (FCR), protein efficiency ratio (PER)) of red tilapia fingerlings after the whole experimental course (112 days) were represented in Table (2). The results showed that there was no significant difference among all treatments and a slightly best FCR and PER values were achieved in T5 (1.41 and 1.78, respectively). 
Table (2): Effect of different T. terrestris and 17- $\alpha$ MT levels on feed and protein utilization (Mean $\pm \mathrm{SE}$ ) of red tilapia fries during 28 days and fingerlings after the whole experimental period (112 days) .

\begin{tabular}{|c|c|c|c|c|c|c|c|}
\hline \multirow{2}{*}{\multicolumn{2}{|c|}{ Feed utilization }} & \multicolumn{6}{|c|}{ Treatments } \\
\hline & & T1 & $\mathbf{T 2}$ & T3 & T4 & T5 & T6 \\
\hline \multirow{6}{*}{ 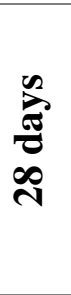 } & \multirow{3}{*}{ FCR } & $2.38^{\mathrm{e}}$ & $1.18^{\mathrm{ab}}$ & $1.08^{\mathrm{a}}$ & $1.59^{\mathrm{c}}$ & $1.41^{\mathrm{bc}}$ & $2.06^{\mathrm{d}}$ \\
\hline & & \pm & \pm & \pm & \pm & \pm & \pm \\
\hline & & 0.07 & 0.15 & 0.02 & 0.07 & 0.04 & 0.04 \\
\hline & \multirow{3}{*}{ PER } & $1.05^{\mathrm{a}}$ & $2.19^{c}$ & $2.31^{\mathrm{c}}$ & $1.58^{\mathrm{b}}$ & $1.78^{b}$ & $1.22^{\mathrm{a}}$ \\
\hline & & \pm & \pm & \pm & \pm & \pm & \pm \\
\hline & & 0.03 & 0.26 & 0.04 & 0.07 & 0.01 & 0.02 \\
\hline \multirow{6}{*}{ 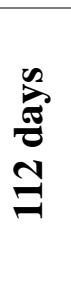 } & \multirow{3}{*}{ FCR } & $1.82^{\mathrm{a}}$ & $1.83^{\mathrm{a}}$ & $1.89^{\mathrm{a}}$ & $1.89^{\mathrm{a}}$ & $1.75^{\mathrm{a}}$ & $1.82^{\mathrm{a}}$ \\
\hline & & \pm & \pm & \pm & \pm & \pm & \pm \\
\hline & & 0.01 & 0.07 & 0.03 & 0.18 & 0.07 & 0.03 \\
\hline & \multirow{3}{*}{ PER } & $1.77^{\mathrm{a}}$ & $1.76^{\mathrm{a}}$ & $1.70^{\mathrm{a}}$ & $1.73^{\mathrm{a}}$ & $1.85^{\mathrm{a}}$ & $1.77^{\mathrm{a}}$ \\
\hline & & \pm & \pm & \pm & \pm & \pm & \pm \\
\hline & & 0.01 & 0.07 & 0.03 & 0.15 & 0.07 & 0.03 \\
\hline
\end{tabular}

*Mean values in the same row with different letters are significantly different $(p<0.05)$

The best FCR and PER values recorded for fish groups treated with experimental inclusion levels ( 1 and $2 \mathrm{~g} \mathrm{~T}$. terrestris / $\mathrm{kg}$ diet) agreed with those of (Omitoyin et al., 2013; Gültepe et al., 2014 and Omar et al., 2014). Additionly, FCR values were significantly better at the hormonal treatments (30, 60 and $100 \mathrm{mg}$ 17- $\alpha$ MT/ kg diet) than that of the control with the best values at $60 \mathrm{mg} 17-\alpha$ MT dose. Those results complied with those of El-Greisy \& El-Gamal (2012) and Rodmongkoldee \& Leelapat (2017) who recommended the same dose (60 $\mathrm{mg})$ of 17- $\alpha$ MT as the best dose in enhancing growth performance of tilapia fry. The enhancement of feed utilization regarding FCR and PER achevied from the inclusion of $T$. terrestris extract to fish feeds may be attributed to their phytochemical compounds which improved feed digestion and nutrient absorbance (Gültepe $\boldsymbol{e t}$ al., 2014). Similarly, Lone \& Matty (1981) concluded that using 17- $\alpha$ MT in fish fry diets improved feed utilization. The insignificant $(p>0.05)$ differences, noted in the present study, among different experimental groups after the whole experimental period (112 days), were confirmed by Omar et al. ( 2014) who found no significant diffrences in growth performance of nile tilapia fry treated with mg 17- $\alpha$ MT and $T$. terrestris for 84 days .

\section{Survival rate:}

Survival rate $\%$ as influenced by varying experimental T.terrestris and $17 \alpha-$ MT levels were shown in Table (3). Survival rates were significantly affected by the different treatments. Both the highest survival rate $(85.44 \%)$ and the lowest survival rate $(71.56 \%)$ were recorded for (T3 and T6, respectively). Comparable results were found in the work of Gültepe et al. (2014 ) and Noor El Deen et al. (2020). The higher survival rates in both T.terrestris extract treatments may be due to the therapeutic properties of the plant extract and several compounds, as vitamins A, C, E, fatty acid and essential amino acid contents (Gharaei $\boldsymbol{e t}$ al., 2020). 
Table (3): Survival rate (Mean \pm SE) of red tilapia fingerlings treated with different sex reversal methods after 112 days.

\begin{tabular}{cc}
\hline Treatments & Survival rate $(\%)$ \\
\hline T1 & $83.11^{\mathrm{a}} \pm 0.77$ \\
\hline T 2 & $83.33^{\mathrm{a}} \pm 1.895$ \\
\hline T3 & $85.44^{\mathrm{a}} \pm 5.78$ \\
\hline T4 & $75.78^{\mathrm{b}} \pm 1.22$ \\
\hline T5 & $76.56^{\mathrm{b}} \pm 2.44$ \\
\hline T6 & $71.56^{\mathrm{c}} \pm 0.676$ \\
\hline
\end{tabular}

* Means followed by different letters in each column are significantly different $(\mathbf{P}<0.05)$.

Lower survival rates were recorded in this study at the hormonal treatment (30, 60 and $100 \mathrm{mg} 17 \alpha-\mathrm{MT} / \mathrm{kg}$ diet). Obviously, these results correlated with those of Marjani et al. ( 2009) and El-Griesy \& El-Gamal, (2012) who observed that treating diets of Nile tilapia fry with $17 \alpha$-MT resulted in significantly higher mortality rates when compared to the control and other hormonal doses. Other studies reported that the inclusion of $17 \alpha-\mathrm{MT}$ in tilapia fry did not affect survival rates (Cruz \& Mair, 1994 and Ajiboye et al., 2015).

\section{Sex ratio:}

Effect of different $T$. terrestris and 17- $\alpha$ MT levels on percentages of males and females of red tilapia fingerlings after the whole experimental period (112 days) were presented in Table (4). The highest male percentage $(\mathrm{p} \leq 0.05)$ was recorded for T5 (60 mg 17- $\alpha$ MT $/ \mathrm{kg}$ feed) treatment recording $90 \%$ followed by T3 (2 g T.terrestris / $\mathrm{kg}$ diet) recording (84.4\%). The significantly lowest male percentage $(\mathrm{p} \leq 0.05)$ was observed in the control group (T1) reporting only $(46.7 \%)$.

Table (4): Sex ratio and survival rate (Mean $\pm \mathrm{SE}$ ) of red tilapia fingerlings treated with different sex reversal methods for 112 days.

\begin{tabular}{ccc}
\hline \multirow{2}{*}{ Treatments } & \multicolumn{2}{c}{ Sex ratio } \\
\cline { 2 - 3 } & $\begin{array}{c}\text { Male percentage } \\
(\boldsymbol{\%})\end{array}$ & $\begin{array}{c}\text { Female percentage } \\
(\boldsymbol{\%})\end{array}$ \\
\hline T1 & $46.7^{\mathrm{c}} \pm 5.0$ & $53.3^{\mathrm{c}} \pm 5.0$ \\
\hline T 2 & $77.8^{\mathrm{ab}} \pm 2.2$ & $22.2^{\mathrm{ab}} \pm 2.2$ \\
\hline T3 & $84.4^{\mathrm{a}} \pm 5.6$ & $15.6^{\mathrm{a}} \pm 5.6$ \\
\hline T4 & $70.0^{\mathrm{b}} \pm 3.8$ & $30.0^{\mathrm{b}} \pm 3.8$ \\
\hline T5 & $90.0^{\mathrm{a}} \pm 5.1$ & $10.0^{\mathrm{a}} \pm 5.1$ \\
\hline T6 & $80.0^{\mathrm{ab}} \pm 5.8$ & $20.0^{\mathrm{ab}} \pm 5.8$
\end{tabular}

* Means followed by different letters in each column are significantly different $(\mathbf{P}<0.05)$.

The highest male percentage was noted in $60 \mathrm{mg}$ of MT/ $\mathrm{kg}$ feed, and comparable results were obtained by Beaven \& Muposhi (2012) and Ajiboye $\boldsymbol{e t}$ al. (2015) who reported a $90 \%$ male percentage at $60 \mathrm{mg} \mathrm{17- \alpha} \mathrm{MT} \mathrm{/} \mathrm{kg}$ feed. However, in their study (2018) Sreenivasa and L Prabhadevi reported a lower male percentage of 86.66 in Nile tilapia fry. Moreover, much higher male percentages $(93 \%$ to $100 \%$ ) were recorded in Nile tilapia fry fed $17-\alpha$ MT at (60 mg / kg feed) (Ali $\boldsymbol{e t}$ al., 2011; Celik et al., 2011 and El-Greisy \& El-Gamal, 2012). The lower male 
percentage recording $80 \%$ in fish group treated with $100 \mathrm{mg} 17 \alpha-\mathrm{MT} / \mathrm{kg}$ diet compared to those of $90 \%$ male recorded for fish group treated with $60 \mathrm{mg} 17 \alpha-\mathrm{MT} /$ $\mathrm{kg}$ diet correlated with the results performed in the studies of Marjani et al. (2009) and Basavaraja \& Raghavendra (2017) reporting lower male percentage in red tilapia fry using the $100 \mathrm{mg}$ of $17 \alpha-\mathrm{MT} / \mathrm{kg}$ feed compared to other lower doses. Hormone suppresses the oogenesis resulting in an inhibitory effect on the oogenesis process which, in return, relies on the concentration of $17 \alpha$-Methyltestosterone administrated in fish diets (Wolf et al., 2004). Thus, it is important to consider the concentration of $17 \alpha$ - MT to avoid the problems attributed to overdoses. Goudie $\boldsymbol{e} t$ al. (1983) reported that high concentrations of the hormone results in sterility. However, sub-optimal doses cause intersexes (Popma \& Green, 1990).

As shown in Table (4), there were significant difference $(\mathrm{P} \leq 0.05)$ among different experimental fish groups. Red tilapia fry treated with $T$. terrestris extract (2 $\mathrm{g} / \mathrm{kg}$ diet) recorded (84.4\%) male percentage compared to $(77.8 \%)$ in group fed $T$. terrestris at $(1 \mathrm{~g} / \mathrm{kg}$ diet $)$, forming a result which agreed with that of Kavitha and Subramanian ( 2011) and Ghosal et al. (2015). The administration of the $T$. terrestris extract at $(2 \mathrm{~g} / \mathrm{kg})$ in the diets of sexually undifferentiated tilapia fry was also found to achieve higher male percentages (91:97\%) (Noor El Deen et al., 2020 and Ghosal \& Chakraborty, 2020) using $2 \mathrm{~g}$. of T. terrestris extract/ $\mathrm{kg}$ feed. The high male percentages obtained from the inclusion of $T$. terrestris extract in the sexually undifferentiated tilapia fry may be attributed to some phytochemical compounds in the plant extract as steroidal saponin protodioscin that may be regarded as androgenic bioactive phytoconstituent that are reported to inhibit the biological synthesis and the action of estrogen working as aromatase inhibitors and antagonists to nuclear estrogen receptor in gonad germ cells (Rempel \& Schlenk, 2008). Concerning the male percentage as affected by hormonal treatment, it could be noted that the higher male percentage (90.0\%) in $60 \mathrm{mg} 17 \alpha-\mathrm{MT} / \mathrm{kg}$ diets compared to male percentages (84.4 and $77.8 \%$ ) in fish groups treated with T.terrestris at ( 2 and $1 \mathrm{~g}$ respectively) agreed with the study of Omar et al. (2014), who recorded a significantly higher male conversion rate $(92.30 \%)$ in the $60 \mathrm{mg} 17 \alpha-\mathrm{MT} / \mathrm{kg}$ feed treatment compared to other T. terrestris extract treatments and the control group.

Pandian and Varadaraj (1990) and Phelps and pompa (2000) stated that male conversion ratio influenced by many genetic and environmental factors (ie, water temperature, the degree of hormone solubility in the solvent, feeding protocol, salinity, photoperiod, stocking density, conditions at the storage of the hormone or the plant extract and also storage conditions of treated feed, and others). Consequently, all the previous factors should be considered to optimize sex-reversal to produce almost all male population of red tilapia, preferably over $98 \%$ male.

\section{Gonads weight and Gonadosomatic index:}

Gonads weight and gonadosomatic index (GSI\%) of red tilapia at the end of the experiment were shown in Table (5). The results showed that the lowest gonads 
weight values in males were obtained from T6 $(0.0102 \mathrm{~g})$ and T5 $(0.022 \mathrm{~g})$. The highest male gonads weight appeared in T2 was $0.0492 \mathrm{~g}$. Gonads weight values in females were higher in T1 $(0.0988 \mathrm{~g})$ and T4 $(0.0852 \mathrm{~g})$, while the lowest female gonads weight values shown in T6 $(0.0255 \mathrm{~g})$ recorded non-significant difference. Considering gonadosomatic index (GSI \%), the highest male GSI\% was shown in T1 $(0.333 \%)$, While the lowest value of males GSI\% was revealed at T6 $(0.0706 \%)$. The highest females GSI\% was in T1 $(0.663 \%)$ and lowest in T6 $(0.175 \%)$.

Table (5): Effect of different T. terrestris extract and 17- $\alpha$ MT levels on gonad weight (GW) and gonadosomatic index (GSI) of red tilapia fingerlings after the whole experimental period (112 days) . (data with mean $\pm \mathrm{SE}$ )

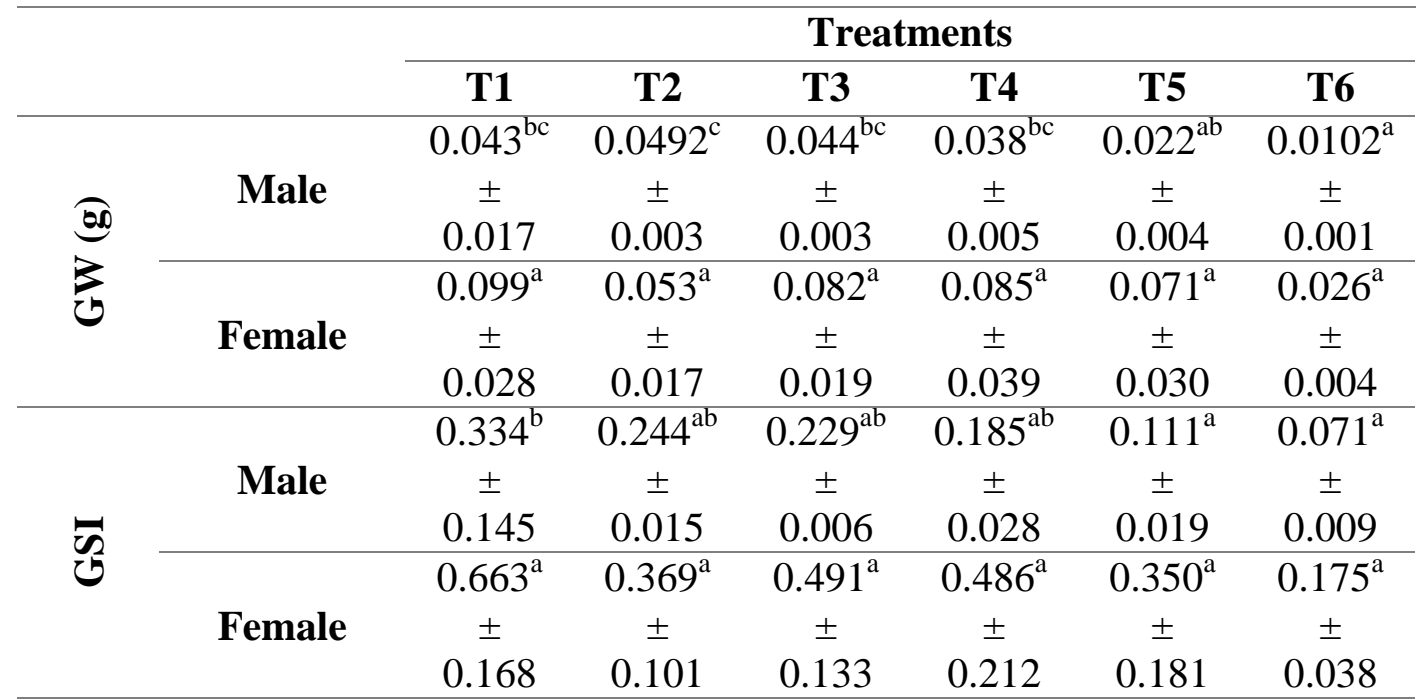

*Mean values in the same row with different letters are significantly different $(p<0.05)$

The present study showed that the two T. terrestris extract treatment (T2 and T3) achieved a higher testes weight than the MT treatment $(\mathrm{p} \leq 0.05)$ with the highest testes weights at the $2 \mathrm{gm} / \mathrm{kg}$ diet treatment which was also significantly higher than all treatments and the control. These findings are in coincides with the Hassona et al. (2020) who reported that the dietary treatment with Tribulus terrestris resulted in better growth performance and better testes weight and gonadosomatic index of male Nile tilapia than the control and MT treatments $(\mathrm{p} \leq 0.05)$.

The lowest development of testes in terms of testes weight and GSI\% values

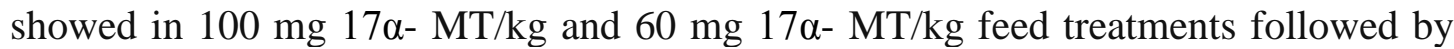
$30 \mathrm{mg}$ 17 $\alpha-\mathrm{MT} / \mathrm{kg}$ were congruent with the values reported in the study of Basavaraja and Raghavendra (2017) who observed a reduction in GSI\% of red tilapia males at a dose of $75 \mathrm{mg} 17 \alpha-\mathrm{MT} / \mathrm{kg}$ diet. In their study (2002) Ahmed et al. realized that $\mathbf{1 7} \boldsymbol{\alpha}$-methyltestosterone effect on fish gonads is complex. Macintosh $\boldsymbol{e t}$ al. (1987) reported that the highest doses of $17 \alpha-\mathrm{MT}(60 \mathrm{mg} / \mathrm{Kg}$ of feed) results in some degeneration of testes which decrease the GSI\% in males. In contrast, Farkhanda et al. (2010) found no significant differences in GSI\% between the MT treatments and the control. However, ovaries weight and gonadosomatic index in females were slightly higher in the control and was recorded the lowest at $100 \mathrm{mg}$ $17 \alpha-\mathrm{MT} / \mathrm{kg}$ feed treatments with no significant difference among all treatments which agreed with the results of Yılmaz et al. ( 2013). 


\section{CONCLUSION}

It is concluded that the inclusion of T.terrestris extract at $1 \mathrm{~g}$ and $2 \mathrm{~g} / \mathrm{kg}$ in diets of red tilapia fry diets and also the oral administration of $17 \alpha-\mathrm{MT}$ at $60 \mathrm{mg} / \mathrm{kg}$ diet could acheive high masculinization percentage in tilpia population and enhancing growth performance and feed utilization of the fish. The upper- mentioned results may help in optimizing seed production practices in red tilapia hatcheries in Egypt and, hence, may control wild spawning problems.

\section{REFERENCES}

Ahmad, M.; Abdel-Tawwab, M.; Shalaby, A. and Khattab, Y. (2002). effects of 17 a-methyltestosterone on growth performance and some physiological changes of nile tilapia, oreochromis niloticus.) fingerllngs. Egyptian Journal of Aquatic Biology and Fisheries, 6 (2): 1-23.

Ajiboye, O. O.; Okonji, V. A. and Yakubu, A. F. (2015). Effect of Testosteroneinduced Sex Reversal on the Sex Ratio, Growth Enhancement and Survival of Nile Tilapia (Oreochromis niloticus) Fed Coppens and Farm Produced Feed in a Semi Flow-through Culture System. Fisheries and Aquaculture Journal, 6 (2): 1.

Ali Abumhara, A.; Mahmoud Yadem, S. and Sovjak, R. (2011). Effect of hormonal treatment on sex reversal of Nile Tilapia (Oreochromis niloticus) fry. Agricultura Tropica et Subtropica (Czech Republic).

Allan, L. and Miller, N. D. (1996). Antioxidant flavonoids: structure, function and clinical usage. Alternative Med. Rev, 1: 111.

Amtyaz, K. M.; Khan, M. Z. and Hashmi, M. U. A. (2013). Studies on gonadosomatic index \& stages of gonadal development of striped piggy fish, pomadasys stridens (Forsskal, 1775) (Family; Pomadasyidae) of Karachi Coast, Pakistan. Journal of entomology and zoology study, 1 (5): 28-31.

Basavaraja, N. (1991). Effects of feeding high levels of 17 $\alpha$-methyl testosterone on the sex ratio and growth of two sizes of Oreochromis mossambicus (Peters). Indian Journal of Animal sciences, 61 (7): 775-779.

Basavaraja, N. and Raghavendra, C. H. (2017). Hormonal sex reversal in red tilapia (Oreochromis niloticus and Oreochromis mossambicus) and inheritance of body colour in $O$. mossambicus and red tilapia: implications for commercial farming. Aquaculture international, 25 (3): 1317-1331.

Beaven, U. and Muposhi, V. (2012). Aspects of a monosex population of Oreochromis niloticus fingerlings produced using 17- $\alpha$ methyl testosterone hormone. Journal of Aquaculture and Research Development, 3 (3): 1-5.

Celik, I.; Guner, Y. and Celik, P. (2011). Effect of orally-administere d 17 $\alpha$ methyltestosterone at different doses on the sex reversal of the Nile tilapia ( Oreochromis niloticus, Linneaus 1758). Journal of Animal and Veterinary Advances, 10 (7): 853-857.

Cruz, E. M. V. and Mair, G. C. (1994). Conditions for effective androgen sex reversal in Oreochromis niloticus (L.). Aquaculture, 122 (2-3): 237-248. 
Ekwu, A. O. and Sikoki, F. D. (2001). Comparison of hormonally induced sex direction in two strains of Oreochromis niloticus (Trewavas). Journal of Aquatic Sciences, 16 (2): 147-149.

El-Greisy, Z. A. and El-Gamal, A. E. (2012). Monosex production of tilapia, Oreochromis niloticus using different doses of $17 \alpha$-methyltestosterone with respect to the degree of sex stability after one year of treatment. The Egyptian Journal of Aquatic Research, 38 (1): 59-66.

FAO. (2020). The state of world fisheries and aquaculture 2020. Sustainability in action. Food and Agriculture Organization of the United Nations.

Farkhanda, A.; Iftikhar, A.; Muhammad, S. and Tahira, I. (2010). Hormonal masculinization and growth performance in Nile tilapia (Oreochromis niloticus) by androgen administration at different dietary protein levels. International Journal of Agriculture and Biology, 12 (6): 939-943.

Fuentes-Silva, C.; Soto-Zarazúa, G. M.; Torres-Pacheco, I. and Flores-Rangel, A. (2013). Male tilapia production techniques: A mini-review. African Journal of Biotechnology, 12 (36): 5496-5502.

Gabriel, N. N.; Qiang, J.; Ma, X. Y.; He, J.; Xu, P. and Omoregie, E. (2017). Sexreversal effect of dietary Aloe vera (Liliaceae) on genetically improved farmed Nile tilapia fry. North American Journal of Aquaculture, 79 (1): 100-105.

GAFARD (2018). General Authority for Fish Resources Development (2018), Fish statistics, the Ministry of Agriculture and Land Reclamation yearbook. Cairo, Egypt.

Gauthaman, K. and Ganesan, A. P. (2008). The hormonal effects of Tribulus terrestris and its role in the management of male erectile dysfunction-an evaluation using primates, rabbit and rat. Phytomedicine, 15 (1-2): 44-54.

Gharaei, A.; Ebrahimi Jorjani, H.; Mirdar Harijani, J. and Kolangi Miandare, H. (2020). Effects of Tribullus terrestris extract on masculinization, growth indices, sex determination reversal and steroid hormones level in Zebra fish (Danio rerio). International Aquatic Research, 12 (1): 22-29.

Ghosal, I. and Chakraborty, S. B. (2020). Production of monosex all-male nile tilapia using ethanol extract of tribulus terrestris seeds. In Proceedings of the Zoological Society, 73 (2): 188-191

Ghosal, I.; Mukherjee, D.; Hancz, C. and Chakraborty, S. B. (2015). Efficacy of Basella alba and Tribulus terrestris extracts for production of monosex Nile tilapia, Oreochromis niloticus. Journal of Applied Pharmaceutical Science, 5 (8): 152-158.

Goudie, C. A.; Redner, B. D.; Simco, B. A. and Davis, K. B. (1983). Feminization of channel catfish by oral administration of steroid sex hormones. Transactions of the American Fisheries Society, 112 (5): 670-672.

Guerrero, R. D. and Guerrero, L. A. (1988). Feasibility of commercial production of sex-reversed Nile tilapia fingerlings in the Philippines. In The Second International Symposium on Tilapia in Aquaculture. ICLARM Conference Proceedings, Vol. 15:. 183-186. 
Gültepe, N.; Acar, Ü.; Kesbiç, O. S.; Yılmaz, S.; Yıldırım, Ö. and Türker, A. (2014). Effects of dietary Tribulus terrestris extract supplementation on growth, feed utilization, hematological, immunological, and biochemical variables of Nile tilapia Oreochromis niloticus. The Israeli Journal of Aquaculture-Bamidgeh. 66: 18.

Hassona, N. N.; Zayed, M. M.; Eltras, W. F. and Mohamed, R. A. (2020). Dietary supplementation of Tribulus terrestris extract improves growth and reproductive performances of the male Nile tilapia (Oreochromis niloticus). Aquaculture Research, 51(10): 4245-4254.

Kavitha, P. and Subramanian, P. (2011). Effect of Tribulus terrestris on monosex production in Poecilia latipinna. Current Science, 101(1): 100-104.

Khakong, S.; Leelarasamee, K.; Suwannasang, A. and Sukkasem, N. (2011). Effects of natural extracts from mangosteen leaves on sex-reversal in Nile tilapia (Oreochromis niloticus). KhonKaen Agriculture Journal, 39: 53-58.

Khouraiba, H. M. (1997). Effect of $17 \alpha$-methyltestosterone on sex reversal and growth of Nile Tilapia, Orechromis niloticus. Zagazig Journal of Agricultural Research, 24: 753-767.

Kumar, M.; Soni, A. K.; Shukla, S. and Kumar, A. (2006). Chemopreventive potential of Tribulus terrestris against 7, 12-dimethylbenz (a) anthracene induced skin papillomagenesis in mice. Asian Pacific Journal of Cancer Prevention, 7 (2): 289.

Lone, K. P. and Matty, A. J. (1981). The effect of feeding androgenic hormones on the proteolytic activity of the alimentary canal of carp Cyprinus carpio L. Journal of Fish Biology, 18 (3): 353-358.

Macintosh, D. J.; Singh, T. B.; Little, D. C. and Edwards, P. (1987). Growth and sexual development of $17 \alpha$-methyltestosterone-and progesterone-treated Nile tilapia (Oreochromis niloticus) reared in earthen ponds. In The Second International Symposium on Tilapia in Aquaculture, ICLARM Conference Proceedings, 15: 457-463.

Marjani, M.; Jamili, S.; Mostafavi, P. G.; Ramin, M. and Mashinchian, A. (2009). Influence of 17-alpha methyl testosterone on masculinization and growth in tilapia (Oreochromis mossambicus). Journal of Fisheries and Aquatic Science, 4(1): 71-74.

Noor El Deen, A. I.; Zaki, M. S. and Shafi, M. E. (2020). Assessment Tribulus terrestris on sex-reverse on Nile Tilapia with respect to its chemical composition. Researcher Journal, 12 (3): 6-11.

Norbeck, L. A. and Sheridan, M. A. (2011). An in vitro model for evaluating peripheral regulation of growth in fish: effects of $17 \beta$-estradiol and testosterone on the expression of growth hormone receptors, insulin-like growth factors, and insulin-like growth factor type 1 receptors in rainbow trout (Oncorhynchus mykiss). General and Comparative Endocrinology, 173 (2): 270-280.

Omar, E. A.; Yousef, M. I.; Srour, T. M. and Mansour, A. T. (2014). Effect of dietary natural phytochemicals on sex-reversal, growth performance, feed utilization and body composition of Nile tilapia (Oreochromis niloticus) fry. Journal of Advance Agricultural Research, 19: 428-441. 
Omitoyin, B. O.; Ajani, E. K. and Sadiq, H. O. (2013). Preliminary investigation of Tribulus terrestris (Linn., 1753) extracts as natural sex reversal agent in Oreochromis niloticus (Linn., 1758) larvae. International Journal of Aquaculture, 3: 74-76.

Pandian, T. J. and Varadaraj, K. (1990). Techniques to produce 100 percent male tilapia. Naga, The ICLARM Quarterly, 13 (3): 3-5.

Phelps, R. P. and Popma, T. J. (2000). Sex reversal of tilapia. Tilapia aquaculture in the Americas, 2: 34-59. Publisher, World Aquaculture Society. City, Baton Rouge.

Popma, T. J. and Green, B. W. (1990). Sex reversal of tilapia in earthen ponds. International conference for Aquaculture and Aquatic Environments Res. And Development. Series No.35, Auburn University, Alabama, pp: 15.

Rempel, M. A. and Schlenk, D. (2008). Effects of environmental estrogens and antiandrogens on endocrine function, gene regulation, and health in fish. International Review of Cell and Molecular Biology, 267: 207-252.

Rodmongkoldee, M. and Leelapat, W. (2017). Effect of feed type on growth performance and sex reversal of Nile tilapia (Oreochromis niloticus). Burapha Science Journal, 22 (1): 14-23.

Sreenivasa, V. and Prabhadevi, L. (2018). Optimization of hormone induced all male production of oreochromis niloticus under laboratory condition at Ambo, Ethiopia. Acta Scientific Agriculture, 2 (4): 16-21.

Statistical Package for the Social Sciens (SPSS) version 22., (2014). IBM Corp. Released 2013. IBM SPSS Statistics for Windows,. Armonk, NY: IBM Corp.

Thodesen, J., Rye, M.; Wang, Y. X.; Li, S. J.; Bentsen, H. B.; Yazdi, M. H. and Gjedrem, T. (2013). Genetic improvement of tilapias in China: genetic parameters and selection responses in growth, survival and external color traits of red tilapia (Oreochromis spp.) after four generations of multi-trait selection. Aquaculture, 416: 354-366.

Tveiten, H.; Mayer, I.; Johnsen, H. K. and Jobling, M. (1998). Sex steroids, growth and condition of Arctic charr broodstock during an annual cycle. Journal of Fish Biology, 53 (4): 714-727.

Ugonna, B. O.; Solomon, S. G.; Olufeagba, S. O.; and Okomoda, V. T. (2018). Effect of Pawpaw carica papaya seed meal on growth and as a natural sex-reversal agent for Nile tilapia. North American Journal of Aquaculture, 80 (3): 278-285.

Wolf, C. J.; LeBlanc, G. A. and Gray Jr, L. E. (2004). Interactive effects of vinclozolin and testosterone propionate on pregnancy and sexual differentiation of the male and female SD rat. Toxicological Sciences, 78 (1): 135-143.

Yılmaz, E.; Çek, Ş. and Mazlum, Y. (2013). Effects of synthetic and natural steroids on the growth, sex reversal and gonadal development of rainbow trout, Oncorhynchus mykiss (Walbaum). Su Ürünleri Dergisi, 30 (3): 123 - 131. 


\title{
الملخص العزبي
}

\section{تقييم معاملات مختلفة لعكس الجنس فى البلطى الأحمر الهجين

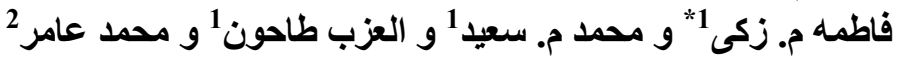

\author{
1- قسم الاستزر اع المائى- كلية الثروة السمكية- جامعة السويس- السويس- مصر \\ 2- قسم الإنتاج الحيو انىـ كلية الزر اعة- جامعة عين شمس- القاهرة- مصر
}

أجريت هذه الدر اسة لتقييم أثر استخدام مستخلص نبات الحسك و أيضاً أثر استخدام هرمون التستستيرون

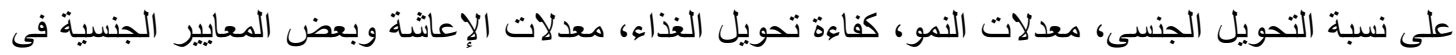

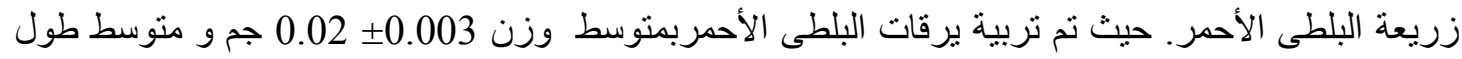

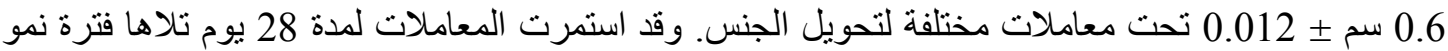

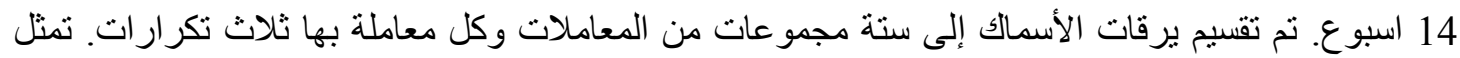

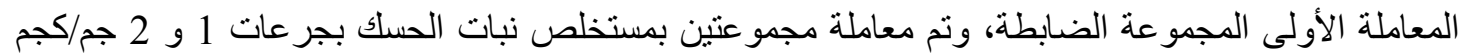

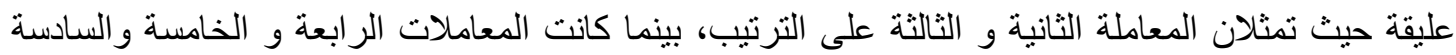

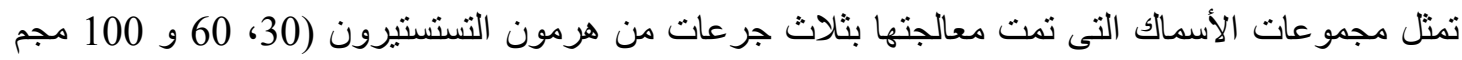
وقد أوضحت نتائج الدر اسة أن جميع معاملات مستخلص نبات الحسك و هرمون التستستيرون قد حققت

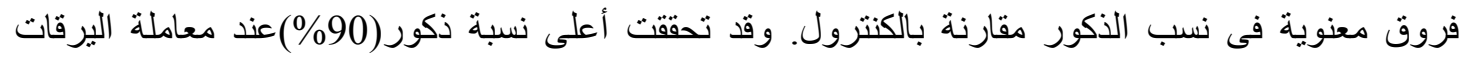

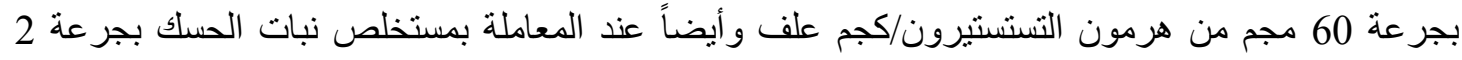

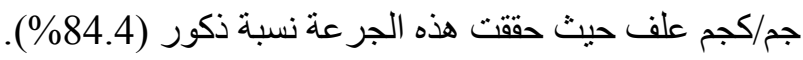

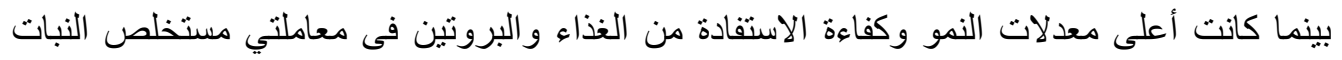

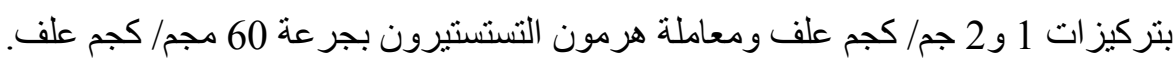

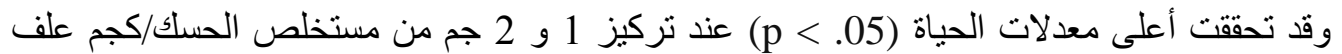

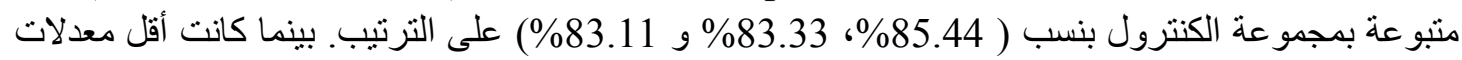

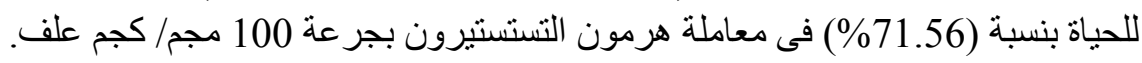

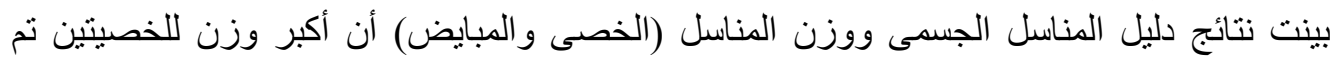

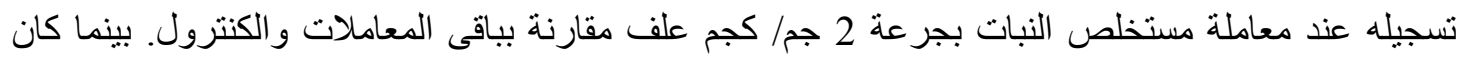

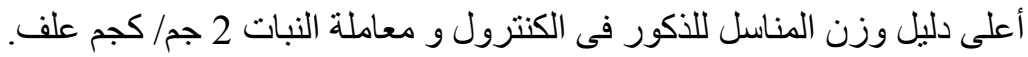

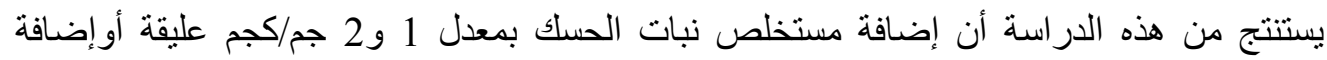

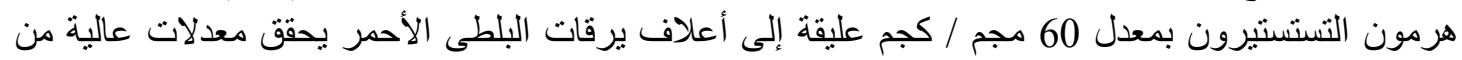
الذكورة ويحسن من معدلات النمو وكفاءة الاستفادة من الغذاء و البروتين لهذه الأسماك. 